\title{
PARADOKS ARROW, PERTUMBUHAN EKONOMI DAN RENCANA PEMBANGUNAN JANGKA MENENGAH NASIONAL (RPJMN) TAHUN 2004-2009
}

\author{
Sayuti Hasibuan \\ Program Pascasarjana Universitas Muhammadiyah Surakarta \\ E-mail: sayutimm@yahoo.co.id
}

\begin{abstract}
Based on past experience as well as implementation paradigms embedded in the five-year plan 2004-2009, there is a very small likelihood that it can be successfully implemented. In the past before the crises of 1997, for a long time economic growth has been on average $6.8 \%$ per year. But that did not prevent open unemployment from rising. The plan target of reducing open unemployment to $5.1 \%$ in 2009 from about $9.7 \%$ in 2005 with $6.6 \%$ yearly average of economic growth appears very unrealistic. This unrealism is the more so because the plan as it stands embodies paradoxes in its various agendas and programs of action resulting from the operation of Arrow's impossibility theorem. While the plan aims at increasing productive employment, its assumption of human being as a resource is a passive, order receiving rather than an active, innovative and risk taking one.

More fundamentally, even if the plan target of economic growth is achieved, it, being on the physical plane, will fail, as it has in the past, to translate the spiritual and corporeal values of Belief in One God and Just and Enlightened Humanity contained in the 1945 constitution. Indonesian society will move further and further away from the cherished ideals of the founding fathers of the Republic with dire implications on its future prosperity and even of its existence. It has been proposed that the operational objective of maximizing economic growth be replaced by maximizing human capability which is more suited to accommodate the multiplicity of objectives in the 1945 constitution with the different levels of physical, corporeal and spiritual dimensions.
\end{abstract}

Keywords: economic and growth devekopment,spiritual value

\section{PENDAHULUAN}

Sudah sejak lebih dari setahun yang lalu diluncurkan Rencana Pembangunan Jangka Menengah Nasional Tahun (RPJMN) 20042009. Dari dokumen ini disusun Agenda 100 Hari Pertama Kabinet Indonesia Bersatu. Mengenai pelaksanaan Agenda 100 Hari Pertama, ini sudah merupakan sejarah yang kesimpulannya adalah -menurut banyak pihak- pelaksanaan tersebut mengalami kegagalan. Yang penting untuk diteliti adalah dokumen lainnya, yaitu RPJMN, sebab Agenda 100 Hari Pertama tersebut diturunkan dari RPJMN. Sejauh manakah kemungkinan berhasilnya dilaksanakan isi 
dokumen tersebut dalam rangka pembangunan Indonesia?

Mengacu kepada pengalaman-pengalaman yang ada, masa lalu maupun kini, dan didukung pula oleh kesimpulan teoritis "teorema ketidakmungkinan" dari Kenneth Arrow, seorang pemenang nobel ilmu ekonomi, maka dapat disampaikan bahwa kemungkinan keberhasilan adalah kecil sekali dan sebaliknya resiko kegagalan cukup besar. Resiko ini bersumber dari banyak hal antara lain kurang atau tidak adanya fokus, manajemen yang reaktif, kurang inisiatif dari para pelaksana, kurangnya kordinasi kegiatan serta terjadinya akibat-akibat yang tidak dikehendaki yang bersifat negatif seperti korupsi, demoralisasi dan lain-lain.

\section{MEMBANGUN KEMAMPUAN BANGSA DAN TEOREMA KETIDAKMUNGKINAN}

\section{Pendekatan Individualistik Tidak Bisa Digunakan Karena Menimbulkan Paradoks Sistemik}

Pertanyaan pokok yang memerlukan jawaban adalah bagaimana membangun kemampuan bangsa untuk merealisasikan berbagai sasaran dalam rangka mewujudkan masyarakat madani bermoral dan berdaya saing tinggi? Apakah bisa ditempuh secara prinsip cara-cara individualistik yang digunakan dalam konteks mengupayakan pertumbuhan ekonomi tinggi? Kalau tidak bisa, cara bagaimana yang bisa ditempuh?

Pendekatan individualistik, sebagaimana yang ditempuh dalam mengupayakan pertumbuhan ekonomi tinggi selama ini, jelas tidak tepat untuk dipergunakan. Pendekatan individualistik ini tercermin dalam perumusan sasaran pembangunan yaitu bahwa yang dituju bukan saja pertumbuhan ekonomi tinggi tetapi juga pertumbuhan pendapatan per kapita yang tinggi. Jadi yang diutamakan adalah peningkatan kekayaan orang per orang. Cara ini tidak tepat untuk ditempuh karena dengan pendekatan individualistik tidak bisa secara prinsip membangun kebersamaan dan oleh karena itu tidak bisa digunakan untuk membangun kemampuan bersama. Cerminan dari ketidakcocokan pendekatan individualistik membangun kebersamaan adalah tidak kunjung bisa ditemukan rumusan operasional kelembagaan yang berkelanjutan membangun kordinasi di antara berbagai unit unit kelembagaan yang independen dalam pembangunan Indonesia dalam kurun waktu berpuluh puluh tahun terakhir ini. Dalam kaitan ini akan dibahas di bawah ini kasus pelaksanaan program 100 hari kabinet SBYKalla. Tetapi sebelum membahas kasus ini, ingin disampaikan dahulu jawaban kenapa tidak bisa bahkan tidak mungkin dibangun kebersamaan dan kordinasi. Ini berkaitan dengan penemuan seorang ekonom, Kenneth Arrow, dalam disertasinya berpuluh-puluh tahun yang lalu.

\section{Kebersamaan dan Paradoks Kenneth Arrow}

Bilamana dipergunakan pendekatan individualistik dalam suatu sistem pelaksanaan maka akan berlaku teorema ketidak mungkinan; yaitu tidak mungkin dicapai suatu kesepakatan di antara dua atau lebih orang/pihak mengenai apa yang menjadi prioritas utama. Teorema ini disebut "Arrow's impossibility theorem" atau "Arrow's paradox". "Arrow's theorem states that there is no general way to aggregate 
preferences without running into some kind of irrationality or unfairness".

Pembuktian secara matematika pernyataan di atas dapat dijumpai dalam tulisan John Geanakoplos (2001). Tetapi secara sederhana, bukti ini dapat dikemukakan sebagai berikut. Anggap ada dua orang/pihak, $\mathrm{K}$ dan $\mathrm{Y}$ yang harus menentukan urutan prioritas dari tiga pilihan yatu A, B dan C. Mana di antara ketiga pilihan yang dianggap sebagai prioritas utama? Umpamakan $\mathrm{K}$ membuat ranking $A>B>C$. Jadi bagi si $K, A>C$. Sedangkan $Y$ membuat pilihan $\mathrm{B}>\mathrm{C}>\mathrm{A}$. Pilihan-pilihan ini harus memenuhi beberapa persyaratan antara lain dilakukan secara bebas oleh masing masing pihak, tidak ada tekanan bahwa pilihan seseorang harus diikuti (semua orang ikut memilih) dan pilihan harus bersifat transitif, artinya kalau dikatakan $A>B>C$, maka mestilah dianggap $A>C$, sebagaimana pilihan $\mathrm{K}$. Sedangkan menurut $\mathrm{Y}$, yang pilihannya juga memenuhi persyaratan teorema, $\mathrm{C}>\mathrm{A}$; berlawanan dengan apa yang disusun oleh $\mathrm{K}$. Di sini jelas terlihat terdapat suatu paradoks.

Tentu kalau jumlah orang yang terlibat banyak dan pilihan juga berjumlah banyak, seperti halnya dalam suatu sistem pelaksanaan pembangunan, apalagi dalam pembangunan Indonesia yang penduduknya penuh kebhinekaan dan jumlahnya besar serta tersebar di daerah geografis yang luas yang mencakup daratan dengan belasan ribu pulau dan lautan, yang kekayaan alamnya banyak diincar oleh tetangga-tetangga yang materialistik, maka dapat dibayangkan berapa banyak paradoks yang akan muncul jikalau tidak ditempuh kebijakan pelaksanaan yang tepat. Paradoks-paradoks inilah yang pada dasarnya berakibat pada besar atau kecilnya dampak suatu pertumbuhan ekonomi bagi pencapaian tujuan-tujuan pembangunan termasuk lapangan kerja. Semakin sedikit paradoks semakin besar dampak pertumbuhan ekonomi terhadap lapangan kerja. Semakin banyak paradoks dalam sistem manajemen perekonomian semakin sedikit dampak pertumbuhan ekonomi bagi lapangan kerja. Jadi kalau diinginkan adanya perluasan lapangan kerja produktif yang lebih besar dari tingkat pertumbuhan ekonomi tertentu, maka paradoks-paradoks perlu dihapuskan sejauh mungkin.

\section{Paradoks dan Lapangan Kerja}

Bagaimana kaitan paradoks-paradoks ini dengan lapangan kerja? Adanya paradoksparadoks ini berarti tidak ada koodinasi dan sinergi di antara berbagai pihak pada berbagai tingkatan yang melaksanakan pilihan-pilihan di dalam sistem pelaksanaan. Koordinasi di sini perlu diartikan luas. Pertama adalah hubungan sinergi antara satu program kegiatan dengan program lainnya; umpamanya agenda pembangunan ekonomi dengan agenda pembangunan hukum dan politik. Kedua adalah hubungan sinergi di dalam satu program; umpamanya hubungan saling tunjang di antara berbagai kegiatan dalam pembangunan ekonomi. Ketiga adalah hubungan sebuah program dengan program yang lebih tinggi; umpamanya adalah hubungan antara program pembangunan ekonomi dengan program umum yang tersimpul di dalam Pembukaan UUD 1945. Kalau semua hubungan ini baik, maka hal ini akan meningkatkan kadar efisiensi dan efektifitas dari segi sasaran-sasaran yang mau dicapai terutama lapangan kerja. Hubungan-hubungan yang demikian inilah 
agaknya yang kurang terjadi dengan program 100 hari kabinet SBY-JK dan di dalam kasus-kasus lain.

\section{Pelaksanaan Program 100 Hari SBY-JK}

Banyak pihak menilai pelaksanaan program kerja 100 hari Kabinet SBY-Kalla kurang berhasil. Dalam jajak pendapat yang dilakukan majalah Tempo, terhadap pertanyaan "Menurut Anda, apakah Presiden Susilo Bambang Yudhoyono telah memenuhi harapan publik dalam seratus hari pemerintahannya?", dari 780 peserta, 573 atau 73,46\% menjawab "Tidak" (Majalah Tempo, 31 Jan-6 Feb 2005:9).

Banyak faktor di belakang tanggapan kekurangberhasilan ini. Ada faktor kompetensi masing masing menteri dalam menanggapi program kerja di bidang masingmasing. Ada faktor lingkungan khususnya gempa-tsunami di Aceh dan Sumatera Utara yang menyita banyak perhatian Presiden dan Wakil Presiden serta beberapa menteri. Namun faktor utama adalah tidak adanya kejelasan dan ketegasan mengenai fokus dan prioritas sehingga alokasi waktu dan perhatian yang langka dapat dilakukan dengan efisien. Fokus, prioritas dan kerangka waktu pencapaian sasaran inilah yang tidak terlihat pada Agenda 100 Hari Pertama Kabinet Indonesia Bersatu. Memang telah ditetapkan tiga agenda yaitu:

Agenda 1: Mewujudkan Indonesia yang Aman dan Damai

Agenda 2: Mewujudkan Indonesia yang Adil dan Demokratis

Agenda 3: Mewujudkan Indonesia yang Sejahtera
Namun dapat ditanyakan lebih lanjut, ketiga agenda ini difokuskan kepada apa dalam 100 hari secara keseluruhan. Apa fokus program 100 hari secara keseluruhan, dimana ketiga agenda tersebut menjadi komponen-komponennya? Fokus inilah yang tidak ada. Tidak ada fokus berarti tidak ada agenda operasional bersama yang jelas dan tegas (tegas artinya tegas untuk yang seratus hari itu) yang ditetapkan bersama atau ditentukan dari atas yang akan memaksa semua pihak melakukan pilihan sesuai agenda yang ditetapkan ini. Dengan kata lain teorema Arrow dibiarkan berlangsung. Sistem pelaksanaan program penuh paradoks. Agenda bersama tidak mungkin dicapai karena tidak diketahui apa itu agenda bersama. Kesalahan berfikir telah menyebabkan kegagalan.

\section{Ketiadaan Program Bersama dalam}

Berbagai Program Pembangunan Lainnya Jangan dikira ketiadaan agenda bersama ini hanya terdapat di bidang makro saja seperti yang terlihat dalam kasus pelaksanaan program 100 hari. Secara mikro hal ini terlihat dalam pembangunan industri. Sebagai contoh adalah pembangunan agroindustri di bidang kelapa sawit. Suatu studi menyimpulkan posisi Indonesia di bidang industri kelapa sawit sebagai berikut: "Apa yang terjadi sekarang ini membuktikan Indonesia selalu kalah langkah dan industri sawit Indonesia belum sepenuhnya mampu berkembang menjadi industri tangguh yang mampu menjawab tantangan yang ada. Kalangan industri juga mengeluhkan belum jelasnya arah kebijakan pemerintah. Jika tidak bergerak cepat, dikhawatirkan bukan hanya hutan dan keanekaragaman hayati yang rusak, tetapi Indonesia juga hanya 
akan terus menjadi pemasok bahan baku dan buruh bagi Malaysia" (Harian Kompas, 25 Feb 2006:51). Ketidakjelasan arah kebijakan pemerintah tidak memungkinkan penyusunan agenda bersama yang mengikat baik pengusaha, pemerintah dan lain-lain pihak untuk mewujudkan cita-cita menjadi nomor satu di dunia di bidang kelapa sawit. Program pembangunan industri kelapa sawit penuh paradoks. Mulai dari masalah penyediaan benih yang kurang dan banyak yang palsu (Harian Kompas, 25 Feb 2006:55) sampai kepada masalah sosial yang menyangkut petani (Harian Kompas, 25 Feb 2006:53) dan masalah lingkungan (Harian Kompas, 25 Feb 2006:54), semuanya memperlihatkan paradoks-paradoks yang menghambat Indonesia meraih posisi no. 1 di bidang sawit ini. Potensi besar yang ada akan terbuang begitu saja dan semua ini adalah akibat dari kesalahan berfikir para pemimpin.

\section{RPJMN 2004-2009 yang Penuh Paradoks}

1. Ketiadaan kebersamaan atau fokus antaragenda

Bagaimana dengan Rencana Pembangunan Jangka Menengah Nasional 2004-2009, apakah juga berisi banyak paradoks? Jawabnya adalah ya, sebab pola pikir yang terkandung di dalam RPJMN sudah tercermin di dalam program 100 hari pertama yaitu ketiadaan fokus. Program 100 hari pertama diambil dari RPJMN. "Keseluruhan Agenda ini (program 100 hari pertama, pen.) merupakan bagian tidak terpisahkan dan bahkan untuk agenda tertentu merupakan langkah awal dan berkesinambungan dengan Agenda Utama jangka menengah 2005-2009 Kabinet Indonesia Bersatu (Bappenas, 2004:1-2). Tidak adanya fokus dalam program 100 hari merupakan refleksi dari tidak adanya fokus dalam RPJMN 20042009.

Dari Bagian 1, Permasalahan dan Agenda Pembangunan Nasional 2004-2009, diketahui telah ditetapkan Visi Pembangunan Nasional tahun 2004-2009 yang terdiri dari tiga komponen yaitu:

1) Terwujudnya kehidupan masyarakat, bangsa dan negara yang aman, bersatu, rukun dan damai;

2) Terwujudnya masyarakat, bangsa, dan negara yang menjunjung tinggi hukum, kesetaraan, dan hak asasi manusia; serta

3) Terwujudnya perekonomian yang mampu menyediakan kesempatan kerja dan penghidupan yang layak serta memberikan pondasi yang kokoh bagi pembangunan yang berkelanjutan" (Republik Indonesia, 2005:I.1-8).

Tentu dapat ditanyakan apa yang menjadi fokus dari ketiga komponen visi di atas? Di sini kita tidak mempermasalahkan substansi dari visi, yang dipersoalkan adalah bagaimana bisa diwujudkan Indonesia yang dinginkan itu kalau tidak diciptakan dan dilaksanakan sekumpulan kebijakan operasional yang terpadu dalam perencanaan atau konsepsi dan terkoordinasi dalam pelaksanaan. Keterpaduan dan koordinasi itu tidak mungkin kecuali ada fokus yang merupakan alat yang memungkinkan keterpaduan dan koordinasi. Ketiadaan fokus secara operasional berlanjut pada perumusan misi dan pelaksanaannya. Ada tiga komponen misi yang dirumuskan, yaitu:

1) Mewujudkan Indonesia yang Aman dan Damai

2) Mewujudkan Indonesia yang Adil dan Demokratis 
3) Mewujudkan Indonesia yang Sejahtera (Republik Indonesia, 2005:I.1-9)

Perumusan misi di sini agak aneh sebab tidak menambah kategori kegiatan yang berbeda tetapi lebih rinci yang diperlukan untuk mewujudkan visi. Terlepas dari masalah perumusan, maka jelas keterpisahan berlanjut ke bawah. Komponen misi no.1 terlihat mengacu kepada komponen visi no.1, komponen misi no.2 mengacu kepada komponen visi no. 2 , dan komponen misi no. 3 mengacu kepada komponen visi no. 3. Sesungguhnya di sini terlihat ada tiga misi yang mengacu kepada tiga visi. Masing masing kegiatan menginduk kepada masingmasing misi yang terpisah satu dengan lainnya. Pada tingkat misi, teorema ketidakmungkinan Arrow tetap dibiarkan berlangsung.

Ketidakjelasan ini terus mengalir ke bawah. Masing-masing komponen misi diterjemahkan kedalam agenda. Jadi ada tiga Agenda yaitu Agenda Mewujudkan Indonesia yang Aman dan Damai, Agenda Mewujudkan Indonesia yang Adil dan Demokratis, dan Agenda Meningkatkan Kesejahteraan Masyarakat. Masing-masing Agenda memiliki sasaran-sasaran tertentu dan untuk mencapai sasaran-sasaran disusun prioritas kegiatan. Tetapi sasaran-sasaran maupun prioritas kegiatan masing-masing agenda sebagaimana juga agenda-agenda saling terpisah satu dengan lainnya. Dengan kata lain teorema ketidakmungkinan Arrow dibiarkan terus berlangsung ke bawah.

Apa dampak dibiarkannya teorema ketidakmungkinan terus berada dalam sistem manajemen pembangunan? Dampaknya adalah merajalelanya paradoks terutama di tingkat pelaksanaan baik yang bersifat antaragenda atau antarsektor maupun di dalam masing masing agenda atau sektor.

Umpamanya, dalam agenda Mewujudkan Indonesia yang Aman dan Damai terdapat tiga sasaran yaitu meningkatnya rasa aman dan damai, semakin kokohnya NKRI berdasarkan Pancasila, Undang-Undang Dasar 1945, dan Bhinneka Tunggal lka dan sasaran ketiga adalah semakin berperannya Indonesia dalam menciptakan perdamaian dunia Republik Indonesia, 2005:I.1-9). Untuk mencapai sasaran-sasaran ini disusun tujuh program kegiatan yang kesemuanya merupakan prioritas pembangunan. Baik agenda, sasaran, maupun program kegiatan semuanya disusun secara terpisah satu sama lain.

Dalam Agenda Mewujudkan Indonesia yang Adil dan Demokratis terdapat empat sasaran dan untuk mencapai sasaran-sasaran ini akan dilaksanakan empat kelompok kegiatan utama termasuk kegiatan untuk Penciptaan Tata Pemerintahan yang Bersih dan Berwibawa.

Dalam Agenda Meningkatkan Kesejahteraan Masyarakat terdapat lima sasaran dengan 25 kelompok kegiatan utama yang diberi prioritas termasuk Percepatan Pembangunan Infrastruktur. Baik sasaran, agenda, maupun program-program kegiatan telah disusun secara terpisah satu dengan yang lain. Tidaklah mengherankan bilamana dalam pelaksanaan terdapat banyak paradoks. Sebagai contoh, dalam Agenda Meningkatkan Kesejahteraan Rakyat, ada Bab 18 yang berjudul Peningkatan Daya Saing Industri Manufaktur. Tetapi apa yang terjadi setelah setahun RPJMN 2004-2009 diluncurkan adalah keterpurukan dan kehilangan daya saing berbagai cabang industri Indonesia. Sebagai contoh, pasar 
domestik tekstil Indonesia semakin dikuasai oleh impor terutama dari Cina. Dilaporkan bahwa produksi tekstil Indonesia pada tahun 2004 menurun menjadi 560 ribu ton dari 608 ribu ton pada tahun 2001 (Republik Indonesia, 2005). Industri kelapa sawit kalah bersaing dengan Malaysia sebagaimana sudah disampaikan.

Bab 19 dari RPJMN 2004-2009 berbunyi "Revitalisasi Pertanian" Tetapi masalah-masalah pokok yang menyangkut kesejahteraan petani, seperti masalah nilai tukar petani belum jelas bagaimana bisa ditingkatkan. Demikian pula, Bab 21 diberi nama "Peningkatan Pengelolaan BUMN". Tetapi di lapangan diketahui bank utama BMUN, Bank Mandiri dan Bank BNI, masuk "intensive care" Bank Indonesia oleh karena besarnya persentase "NPL" atau hutang bermasalah yang berada di atas ambang batas ketentuan Bank Indonesia.

Adalah paradoks-paradoks baik dalam perencanaan dan dalam pelaksanaan yang mengakibatkan begitu banyak kegagalan dan kekecewaan di kalangan para pelaksana dan masyarakat umumnya.

2. Paradoks utama RPJMN 2005-2009: paradoks vertikal

Sesungguhnya paradoks utama dalam rekayasa pembangunan Indonesia adalah yang menyangkut paradoks vertikal. Paradoks ini adalah berupa tidak sesuainya apa yang direncanakan dalam pembangunan Indonesia dengan apa yang dikehendaki oleh Pembukaan Undang Undang Dasar 1945. Hal ini dapat dilihat dari Bab 34: Kerangka Makro dan Pembiayaan Pembangunan. Di sini ditegaskan bahwa yang menjadi tujuan operasional utama dalam pembangunan bangsa adalah materi dalam bentuk pertumbuhan ekonomi tinggi. Semua agenda pembangunan yang direncanakan yaitu Agenda Menciptakan Indonesia yang Aman dan Damai, Agenda Menciptakan Indonesia yang Adil dan Demokratis dan Agenda Meningkatkan Kesejahteraan Rakyat, pada akhirnya ditujukan untuk meraih pertumbuhan ekonomi yang tinggi. Ini ditegaskan dalam Bab 34. "Kerangka ekonomi makro dan pembiayaan pembangunan memberikan gambaran mengenai kemajuan ekonomi yang akan dicapai dalam tahun 2005-2009, berdasarkan berbagai langkah yang telah dituangkan dalam ketiga agenda pembangunan, pembiayaan dan pembangunannya“ (Republik Indonesia, 2005:V.34-1). Dari kalimat pembuka Bab 34 ini terlihat bahwa fokus utama adalah ekonomi yaitu materi. Dalam ekonomi, fokus utama adalah pertumbuhan ekonomi yang tinggi. Pertumbuhan ekonomi yang tinggi diharapkan akan menghasilkan perbaikan kesejahteraan rakyat, utamanya "penciptaan dan pemerataan lapangan kerja".

Khusus mengenai pertumbuhan ekonomi tinggi sebagai fokus utama pembanguanan maka hal ini tidak sejalan dengan nilai-nilai dalam Pembukaan Undang Undang Dasar 1945. Dalam Undang Undang Dasar 1945 ada unsur Tuhan yang Maha Esa yang bersifat non-materi. Pertumbuhan ekonomi tinggi sebagai idiologi operasional jelas tidak konsisten dengan prinsip Ketuhanan yang Maha Esa yang berisi unsur ghaib. Pertumbuhan ekonomi tidak mungkin menangkap dan mengkomunikasikan nilai nilai spiritual yang berkaitan dengan Tuhan Yang Maha Esa sebab pertumbuhan ekonomi berada pada satu tingkatan realita saja yaitu tingkatan fisik. 
Dalam kaitan dengan lapangan kerja maka pertumbuhan ekonomi tinggi direncanakan rata-rata 2005-2009 adalah $6,6 \%$ per tahun- diharapkan akan menghasilkan lapangan kerja cukup luas sehingga pengangguran terbuka diharapkan turun menjadi 5,1\% pada tahun 2009 (dari 9,7\% pada tahun 2005) (Republik Indonesia, 2005:V.34-5).

Sedangkan dalam kaitannya dengan lapangan kerja produktif, pertumbuhan ekonomi tinggi di masa lalu, yaitu rata-rata sebesar 6,8\% dalam waktu cukup lama sebelum krisis, dengan stabilitas ekonomi yang baik, investasi dan ekspor cukup tinggi, tidak menghindarkan meningkatnya terus pengangguran terbuka. Pengangguran terbuka mencapai jumlah di atas $10 \%$ saat ini (2006) dari 1,7\% pada tahun 1980;3,2\% pada tahun 1990; dan 7,3\% pada tahun 1995 . Dengan lain perkataan, berdasarkan pengalaman masa lalu, dengan pertumbuhan ekonomi yang dituju dalam tahun 2005-2009 sebesar $6,6 \%$ diperkirakan juga tidak akan berhasil menurunkan tingkat pengangguran terbuka.

Tentu paradoks riil yang dirasakan masyarakat ialah bahwa pertumbuhan tinggi menghasilkan ketidakadilan dalam kegiatan pembangunan maupun dalam distribusi hasilhasil pembangunan. Masalah ketidakadilan ini sudah banyak didokumentasikan, antara lain dalam terbitan perdana Jurnal Fakultas Ekonomi Universitas Al Azhar Indonesia, Februari 2006 yang membahas ketidakadilan dalam pelaksanaan pembangunan industri. Pertumbuhan ekonomi tinggi menghasilkan paradoks vertikal dengan prinsip kemanusiaan yang adil dan beradab.
3. Mengurangi pengangguran dan anggapan mengenai manusia

Apa masalah dasar yang dihadapi untuk meningkatkan hubungan positif yang lebih akrab antara pertumbuhan ekonomi dengan lapangan kerja; agar lebih banyak lapangan kerja bisa tercipta untuk setiap unit pertumbuhan ekonomi? Ditinjau dari segi manajemen pembangunan, lapangan kerja atau kesempatan kerja atau "employment", menyangkut manajemen manusia.

Pertama, adalah manusia sebagai penerima hasil pembangunan. Sebagai penerima hasil pembangunan manusia dianggap manusia pasif. Dia menerima dampak saja dari pertumbuhan ekonomi. Kalau dia ikut meningkatkan pertumbuhan ekonomi maka keikutsertaan hanyalah sebagai alat semata. Manusia yang demikian itulah yang tersimpan dalam konsep-konsep makro ekonomi sebagaimana yang tercermin dalam RPJMN 2004-2009. Konsep manusia yang demikian tidak sejalan dengan upaya perluasan lapangan kerja.

Kedua, adalah manusia sebagai agen aktif dalam pembangunan, sebagai promotor dan motor pembangunan dengan mengupayakan pada berbagai tingkatan agar sumber-sumber yang tersedia dimanfaatkan seefektif mungkin dan seefisien mungkin. Konsep manusia seperti yang kedua inilah yang tidak tercermin dalam pola pikir RJPMN ini. Pertanyaan pokok berapa persen pertumbuhan ekonomi yang direncanakan rata rata $6,6 \%$ per tahun bersumber dari modal dan berapa persen bersumber dari sumber daya manusia sama sekali tidak terjawab; bahkan wacananya saja tidak muncul dalam konsep ekonomi makro sebagaimana yang tertuang dalam Bab 34 . 
Apakah ada bukti bahwa pola pikir manusia sebagai agen aktif dalam pembangunan tidak tercermin dalam RPJMN 2004-2009? Bukti-bukti dapat dikemukakan sebagai berikut.

Pertama, adalah keterpisahan antara perencanaan dan pelaksanaan. Pola pikir keterpisahan ini berarti para perencana berbeda manusianya dari pelaksana. Ada sekelompok orang yang tugasnya merencanakan dan ada sekelompok lain yang tugasnya melaksanakan. Ini tercermin dalam susunan bab-bab dalam RPJMN. Bab 1 sampai dengan Bab 34 mengemukakan utamanya hal hal apa yang dikehendaki secara normatif, apa yang ingin dicapai dalam 5 tahun ke depan. Ini dilakukan oleh Presiden dengan bantuan Bappenas dan pihak-pihak lain di bidang perencanaan. Bab 35: "Kaidah Pelaksanaan" menyampaikan utamanya bagaimana mencapai hal-hal yang ingin dicapai. Kaidah pelaksanaan ditujukan utamanya terhadap lembaga, kementerian, dan pemerintahan daerah. Dengan kata lain ada keterpisahan siapa yang merencanakan dengan siapa yang melaksanakan. Lembaga perencana berbeda dengan lembaga pelaksana. Dalam bab ini antara lain disampaikan Rencana Pembangunan Jangka Menengah Nasional Tahun 2005 - 2009 merupakan penjabaran dari visi, misi, dan program Presiden hasil Pemilihan Umum yang dilaksanakan secara langsung pada tahun 2004.

Rencana Pembangunan Jangka Menengah Nasional Tahun 2005 - 2009 merupakan pedoman bagi Kementerian/ Lembaga dalam menyusun Rencana Strategis (Renstra) Kementerian/Lembaga dan merupakan pedoman bagi daerah dalam menyusun Rencana Pembangunan Jangka
Menengah Nasional Tahun 2005-2009 selanjutnya menjadi pedoman bagi penysusanan Rencana kerja Pemerintah" (Republik Indonesia, 2005:VI.35-1). Kutipan-kutipan dari Bab 35 ini menegaskan pemisahan antara perencanaan dan pelaksanaan.

Pemisahan ini mengisyaratkan adanya pola pikir yang berlaku dalam manajemen pada era industri sebelumnya yakni, pola pikir 3K, yaitu, Komando, Kontrol dan Kompartementalisasi. Pola pikir demikian tidak tepat untuk merelalisasikan manusia sebagai sumber pertumbuhan; sebagai manusia yang menjadi promotor perubahan dan inovasi yang amat dibutuhkan di era informasi, ilmu pengetahuan, globalisasi dan perubahan serta demokrasi. Untuk menjadikan manusia sebagai agen aktif mencapai cita cita, aturan main pokok perlu diubah menjadi bukan kontrol tetapi inovasi dan "feedback"; bukan kompartementalisasi tetapi jaringan; bukan komando tetapi kepemimpinan berbasis inspirasi dan komitmen.

Kedua, adalah adanya keterpisahan di antara ketiga agenda dan keterpisahan dalam melaksanakan kegiatan-kegiatan dalam masing-masing agenda. Secara kelembagaan ini berarti masing-masing departemen pelaksana saling terpisah satu dengan yang lain. Masing-masing departemen/lembaga pelaksana diatur oleh wewenang ketat dan sistem birokrasi kaku pada masing masing departemen/lembaga. Inovasi praktis tidak mungkin dalam sistem pelaksanaan yang demikian. Koordinasi sulit dan kalaupun ada, maka koordinasi bersifat ad-hoc dan bukan sistemik. Kreativitas manusia praktis dipasung. Manusia-manusia pelaksana tidak bergerak kecuali ada perintah untuk 
bergerak. Dalam kultur kerja yang demikian tentu praktek 'asal bapak senang' akan berkembang. Lebih parah lagi keikhlasan dan komitmen melaksanakan tugas tidak terpupuk, kebijakan-kebijakan sulit terlaksana dengan efektif dan efisien.

Sebagai contoh sulitnya pelaksanaan kebijakan adalah pesimisme para pengusaha mengenai pelaksanaan paket kebijakan investasi yang baru-baru ini dikeluarkan pemerintah. "Paket kebijakan itu baik, namun saya bertanya, apakah bisa berjalan? Demikian ucapan Ketua Umum Asosiasi Pengusaha Indonesia, Sofjan Wanandi. Lebih lanjut dia mengemukakan bahwa "Sejak pemerintahan Megawati Soekarnoputri, sudah banyak kebijakan investasi - mulai dari program tahun investasi yang digulirkan, white paper, sampai paket Oktober 2005 pada masa pemerintahan Susilo Bambang Yudhoyono. Contoh lain, mengenai Rancangan Undang-Undang (RUU) tetang Penanaman Modal atau program tahun investasi. Sampai sekarang penyelesaian RUU Penanaman Modal tidak jelas (Harian Kompas, 4 Maret 2006:1). Namun Ketua Umum Kamar Dagang dan Industri (Kadin) dilaporkan menyambut baik kebijakan investasi tersebut. "Wacana sudah banyak. Kebijakan sudah dibuat. Penanggung jawab sudah ditetapkan. Sektor-sektor yang diatur pun sudah ditetapkan. Maka, sekarang kita harus mengimplementasikannya" (Harian Kompas, 4 Maret 2006:15). Ini adalah satu kehendak yang baik.

Langkah apa yang dapat ditawarkan untuk memperbaiki pelaksanaan? Langkah yang dapat ditawarkan meliputi perubahan yaitu perubahan paradigma pelaksanaan dari yang berbasis materi ke yang berbasis manusia dan perubahan dari nilai-nilai moral idiologi operasional buatan manusia semata atau nilai-nilai moral subyektif ke idiologi operasional dengan nilai-nilai moral obyektif berbasis kepada prinsip Ketuhanan Yang Maha Esa. Segala sesuatu perubahan ini dibutuhkan untuk meluruskan jalannya pembangunan nasional.

Adapun kemungkinan berhasilnya pelaksanaan yang kecil dari RPMJN adalah disebabkan rencana ini menggunakan idiologi operasional yang bukan saja menurut pengalaman telah menjadi sumber kegagalan pelaksanaan di masa lalu tetapi juga idiologi operasional materi tidak cocok dengan caracara yang dikehendaki oleh UUD 1945 untuk merealisasikan cita-cita bangsa. Cara-cara pokok yang diamanatkan oleh UUD 1945 untuk mewujudkan cita-cita yang terkandung di dalamnya bukan saja berbasis kemanusiaan tetapi juga kemanusiaan yang berprinsip kepada Ketuhanan Yang Maha Esa. Hal hal ini merupakan bagian yang tidak terpisahkan yang perlu dihormati secara operasional untuk meraih keberhasilan pelaksanaan. Penghormatan ini sulit terjadi kalau idiologi operasional yang dipergunakan bersifat materi.

\section{PERTUMBUHAN EKONOMI TINGGI VS KEMAMPUAN MANUSIA TINGGI}

\section{Kegagalan Pertumbuhan Ekonomi Tinggi Mengejawantahkan Nilai-nilai Dasar dalam Pembukaan UUD 1945}

RPJMN 2005-2009 disusun dengan menggunakan pendekatan materialistik sebagaimana yang dicerminkan oleh pencapaian sasaran pertumbuhan ekonomi tinggi. Hal ini tertulis dalam Bab 34: Kerangka Ekonomi Makro dan Pembiayaan Pembangunan. "Tercapainya Pertumbuhan Ekonomi yang Tinggi". 
Sasaran pertumbuhan ekonomi yang ingin diupayakan adalah 5,5\% pada tahun 2005 dan $7,6 \%$ pada tahun 2009 atau rata rata $6,6 \%$ per tahun" (Republik Indonesia, 2004:V.34-6).

Di masa silam sebelum krisis Indonesia mencapai pertumbuhan ekonomi yang cukup tinggi. "Selama 25 tahun pertumbuhan ekonomi Indonesia mencapai rata-rata 6,8\% per tahun" (Republik Indonesia, 1994:I.83). Ekspor Indonesia meningkat cukup tinggi khususnya ekspor non-migas. "Nilai keseluruhan ekspor meningkat menjadi sekitar 43 kali, yaitu dari US\$872 juta pada tahun 1968 diperkirakan menjadi US\$37,2 miliar pada tahun 1993/94. Peningkatan pesat ini terutama berasal dari ekspor nonmigas yang meningkat menjadi sekitar 50 kali, yakni dari US\$569 juta pada tahun 1968 diperkirakan menjadi US\$28,2 miliar pada tahun 1993/94, dan peranannya mencapai $75,8 \%$ dari nilai seluruh ekspor"(Republik Indonesia, 1994:I.86-87). Investasi juga cukup tinggi. "Dalam PJP I pinjaman luar negeri pemerintah meningkat dari US\$266 juta pada tahun 1968 diperkirakan menjadi US\$5,9 miliar pada tahun 1993/94. ... Pemasukan modal (neto) swasta meningkat dari US\$65 juta pada tahun 1968 diperkirakan menjadi US\$6,7 miliar pada tahun 1993/94, dan penanaman modal asing (neto) meningkat dari US $\$ 10$ juta pada tahun 1968 diperkirakan menjadi US\$2,0 miliar pada tahun 1993/94“ (Republik Indonesia, 1994:I.87). Indonesia dikategorikan sebagai negara dengan ekonomi ajaib.

Namun segala sesuatu tidak bisa bertahan. Dengan serangan relatif kecil dari krisis mata uang Baht di Thailand pada tahun 1997, Indonesia terjerumus ke dalam krisis yang dimulai dari krisis moneter, berkembang menjadi krisis ekonomi dan selanjutnya ke krisis sosial politik dan kebudayaan.

Kenapa tidak bisa dipertahankan posisi ekonomi ajaib menurut ukuran ukuran materialistik itu? Pertumbuhan ekonomi tinggi yang dialami bukan saja tidak berhasil mewujudkan cita-cita keadilan tetapi juga gagal mengembangkan kelembagaan termasuk kepemimpinan yang mampu mendukung pembangunan berkelanjutan. Kegagalan itu terlihat dari semakin meningkatnya pengangguran terbuka dalam perekonomian Indonesia. Pada tahun 1980, pengangguran terbuka berjumlah hanya 891 ribu orang atau $1,7 \%$ dari angkatan kerja. Pada tahun 1990 jumlah pengangguran meningkat menjadi 2365 ribu orang atau meningkat dengan $10.3 \%$ per tahun. Pada tahun 1995, pengangguran terbuka meningkat lagi menjadi 3,2\% dari angkatan kerja atau 6304 ribu orang atau $21,7 \%$ setiap tahun. Pada tahun 2004 yang lalu pengangguran terbuka meningkat lagi menjadi 10251 ribu orang atau 9,9\% dari angkatan kerja ${ }^{1}$, atau sekitar $17-18 \%$ per tahun. Peningkatan ini pada tahun 2004 cukup bermakna sebab definisi angkatan kerja telah berubah dari penduduk 10 tahun keatas yang bekerja atau mencari pekerjaan menjadi penduduk yang berumur 15 tahun ke atas. Perubahan ini tentu cenderung menekan ke bawah jumlah orang yang menganggur. Memang pertumbuhan ekonomi dalam periode $1995 \mathrm{~s} / \mathrm{d} 2004$ berada di bawah $6,8 \%$

\footnotetext{
1. Angka angka pengangguran diperoleh dari berbagai sumber BPS. Pengangguran 1980: Population Census 1980, Series S No.2, Februari 1983. Pengangguran 1990: Population Census 1990, Series S No.2, Juli 1992. Pengangguran 1995: Intercensal Population Survey, 1996, Series S 2, September 1996.
} 
per tahun. Namun satu kesimpulan yang dapat disampaikan ialah bahwa pertumbuhan ekonomi tinggi terlihat tidak punya pengaruh secara fundamental terhadap pengangguran terbuka. Pengangguran terbuka terus tumbuh diatas $10 \%$ per tahun walaupun tingkat pertumbuhan ekonomi yang dicapai tinggi seperti pada masa sebelum krisis. Kalau pertumbuhan ekonomi lebih rendah seperti pada saat setelah krisis, maka pengangguran cenderung meningkat. Apalagi kalau dilihat dari angka separoh pengangguran, yaitu angkatan kerja yang bekerja kurang dari 35 jam per minggu, maka jelas terlihat bahwa petumbuhan ekonomi tinggi tidak mempengaruhi angka ini secara berarti. Dari berbagai sumber BPS, persentase separoh pengangguran ini adalah $36,5 \%$ pada tahun $1980 ; 36,6 \%$ pada tahun 1990 ; dan $36,9 \%$ pada tahun 1995 pada saat pertumbuhan ekonomi tinggi. Kalau pertumbuhan ekonomi rendah, seperti pada saat krisis, separoh pengangguran juga cenderung tinggi yaitu di atas $30 \%$. Pada tahun 2000, separoh pengangguran adalah $36,7 \%$ dan pada tahun 2004 separoh pengangguran adalah $32,2 \%$. $^{2}$ Perlu diperhatikan angka pengangguran menyangkut jumlah manusia, angka riil; bukan ukuran uang yaitu pendapatan atau konsumsi yang diukur dengan uang, seperti halnya ukuran kemiskinan yang bisa naik turun dengan naik turunnya inflasi dan jumlah dana yang disalurkan untuk mengatasi kemiskinan absolut. Kalau pengangguran terbuka terus naik walaupun pertumbuhan ekonomi cukup tinggi, ada sesuatu yang salah secara mendasar dengan sistem pengelolaan perekonomian tersebut.

2. Untuk tahun 2004, website Departemen Tenaga Kerja dan Transmigrasi
Yang salah itu berkaitan dengan idiologi operasional yang dipergunakan dalam manajemen pembangunan sebagaimana sudah disampaikan di atas. Intinya idiologi operasional yang digunakan, yaitu pertumbuhan ekonomi tinggi, tidak tepat sehingga gagal dalam pembentukan kemampuan manusia dan kelembagaan bagi suatu pembangunan yang berkelanjutan termasuk berkelanjutan dari segi sumber daya alam dan lingkungan hidup.

Idiologi artinya sesuatu yang tidak dipersoalkan lagi kebenarannya. Kalau dikatakan bahwa yang dituju dalam pembangunan adalah pertumbuhan ekonomi (tinggi) maka ini artinya pegangan atau pedoman utama secara operasional dalam berbagai kebijakan dan langkah-langkah adalah tercapainya kekayaan materi sebesar mungkin. Mungkin anda bertanya apa yang salah dengan menjadi kaya (secepat mungkin) sebagai pegangan operasional kebijakan? Ingin menjadi kaya sebagai salah satu tujuan tentu tidak ada masalah; sebagaimana tidak ada masalah, -umpamanya- bilamana peningkatan intelektualitas, peningkatan kesehatan, peningkatan mutu lingkungan hidup, dan lain lain, dijadikan sebagai salah satu tujuan kebijakan pembangunan. Permasalahannya ialah bilamana menjadi kaya secara materi dijadikan tujuan utama; masalah menjadi tambah besar bilamana tujuan meningkatkan kekayaan materi dijadikan pegangan operasional utama dalam menentukan pilihan-pilihan dalam kebijakan pembangunan. Ini artinya tujuan maupun cara semuanya berkisar di sekitar materi. Tujuan materialistik diupayakan dengan cara cara materialistik. Lalu kenapa kalau idiologi 
operasional pelaksanaan adalah materialistik?

Persoalannya adalah idiologi operasional materialistik dalam bentuk pertumbuhan ekonomi tinggi berlawanan dengan kesepakatan pokok lima prinsip dasar kemerdekaan Indonesia, yang disebut Pancasila, atas dasar mana kelembagaan di dalam negeri perlu dikembangkan. Prinsipprinsip ini adalah utamanya Ketuhanan yang Maha Esa dan Kemanusiaan yang Adil dan Beradab. Lima prinsip pokok merupakan inti dari "theory of the business" mengenai apa dan bagaimana mencapai cita cita kemerdekaan Indonesia. "Theory of the Business" ini merupakan hasil pengamatan, renungan dan perdebatan di kalangan orangorang hebat pejuang-pejuang pendiri bangsa.

Dalam kenyataannya, idiologi materialistik telah mengembangkan nilai-nilai yang berlawanan dengan nilai-nilai moral obyektif yang terkandung di dalam prinsip Ketuhanan yang Maha Esa dan Kemanusiaan yang Adil dan Beradab, seperti kejujuran dan keadilan. Bentuk-bentuk penyelewengan adalah korupsi, kesenjangan, kejahatan, dan hilangnya kesalehan, dan lain lain. Dengan menganut faham pertumbuhan ekonomi tinggi sebagai pegangan operasional, maka "theory of the business" atas dasar lima prinsip dasar digantikan dengan teori ekonomi neo-klasik di bidang ekonomi dan teori-teori yang sejalan dengan itu dalam berbagai bidang sebagai dasar pembentukan kebijakan.

Jelas yang diperdebatkan di sini bukanlah Pancasila itu tetapi bagaimana melaksanakannya. Kesimpulannya, ideologi pertumbuhan ekonomi tinggi tidak konsisten dengan prinsip-prinsip yang lebih tinggi; jadi oleh karena itu idiologi ini adalah idiologi operasional yang keliru bagi pembangunan Indonesia. Dapatlah disampaikan dengan singkat bahwa dengan idiologi operasional ekonomi tinggi dalam pembangunan, Negara Kesatuan Republik Indonesia telah gagal merumuskan dengan tepat secara otonom apa yang menjadi niat dasar didirikannya negara ini; niat dasar mana tercermin dalam Pembukaan Undang Undang Dasar 1945. Terkait secara paradigmatis dengan kegagalan perumusan niat dasar yang jelas dan tegas, adalah kegagalan dalam membangun kelembagaan dan strukturnya yang mampu mengadakan perubahan dalam struktur sosial ekonomi bangsa dan gagal pula mempertahankan hasil-hasil yang telah dicapai.

Apakah ini berarti bahwa pertumbuhan ekonomi sama sekali tidak dikehendaki? Jawabannya tidak. Pertumbuhan ekonomi tinggi tetap dikehendaki sebab pertumbuhan ekonomi tinggi berarti bertambahnya kekayaan materi masyarakat dengan cepat. Jadi ia tetap dikehendaki apalagi di negeri miskin materi seperti Indonesia. Lalu, apanya dari pertumbuhan ekonomi tinggi yang tidak dikehendaki? Yang tidak dikehendaki adalah ketika pertumbuhan ekonomi tinggi dijadikan basis idiologi operasional dalam mencapai tujuan pembangunan termasuk pertambahan kekayaan materi yaitu pertumbuhan ekonomi tinggi itu sendiri.

Jadi perlu ditegaskan yang tidak dikehendaki itu terdiri dari dua hal yang menyangkut pertumbuhan ekonomi tinggi; yaitu ketika ia dijadikan tujuan utama dan kedua ketika ia dijadikan sekaligus cara utama mencapai tujuan pembangunan termasuk peningkatan kekayaan materi.

Tetapi kenapa tidak dikehendaki? Ini disebabkan ketika pertumbuhan ekonomi 
dijadikan basis idiologi operasional maka terwujudlah secara operasional hal-hal negatif yang tidak dikehendaki di dalam pembangunan. Hal-hal negatif ini menyangkut kegagalan lembaga pelaksanaan sebagaimana yang disampaikan di atas.

Apa hal-hal negatif ini? Pertama, kecenderungan digesernya dari kesadaran pengambilan keputusan sehari-hari pertimbangan-pertimbangan nilai-nilai moral Ketuhanan Yang Maha Esa dan Kemanusiaan, dan menjadi dominannya pertimbangan materi semata. Secara ekstrim hal ini dirasakan dan dapat diamati dalam kasus-kasus penyalahgunaan wewenang dalam berbagai bidang kehidupan seperti di bidang hukum; plesetan Kasih Uang Habis Perkara (KUHP) adalah cerminan peran dominan uang di bidang hukum. Bahkan di rumah-rumah sakit sekalipun, diamati banyaknya pasien yang amat membutuhkan pertolongan medis, tidak dapat ditolong oleh karena ketiadaan uang si pasien. Korupsi pada berbagai bidang dan tingkatan sudah merupakan bagian dari kehidupan bangsa. Lebih jauh digesernya pertimbangan Ketuhanan Yang Maha Esa dan Kemanusiaan dalam kesadaran pengambilan keputusan terlihat dengan jelas di bidang sumber daya alam dan lingkungan hidup, "Illegal logging" umpamanya bukanlah hanya kasus korupsi kekuasaan tetapi strategi maksimisasi keuntungan materi menggantikan pertimbangan kelestarian sumber daya alam dan lingkungan hidup dalam pengambilan keputusan.

Dari titik pandang lain, tergesernya peranan nilai-nilai moral berbasis Ketuhanan yang Maha Esa dalam kesadaran mengambil keputusan berarti tidak adanya pengakuan bahwa Tuhan yang Maha Esa itu turut serta secara aktif menentukan berhasil atau gagalnya pelaksanaan keputusan. Bagaimana kita mengetahui peran aktif Tuhan yang Maha Esa ini? Kita mengetahui dari pemberitaan kitab suci, khususnya, Al Qur'an. Ayat Kursi, salah satu ayat terkenal dari al Qur'an mengemukakan "Allah tidak ada Tuhan (yang berhak disembah) melainkan Dia yang Hidup kekal lagi terus menerus mengurus (makhluk-Nya); tidak mengantuk dan tidak tidur. Kepunyaan-Nya apa yang di langit dan di bumi. Tiada yang dapat memberi syafa'at di sisi Allah tanpa izin-Nya. Allah mengetahui apa-apa yang di hadapan mereka dan di belakang mereka, dan mereka tidak memgetahui apa-apa dari ilmu Allah melainkan apa yang di kehendakiNya. Kursi Allah meliputi langit dan bumi. Dan Allah tidak merasa berat memelihara keduanya, dan Allah Maha Tinggi lagi Maha Benar (Q.S. 2: Al Baqarah 255)

Apa konsekwensi operasional dari kesadaran bahwa Tuhan yang Maha Esa turut serta aktif dalam proses manajemen kegiatan-kegiatan pelaksanaan? Anggaplah para pelaksana (PL) khususnya para pimpinan mengadakan dialog dengan Tuhan yang Maha Esa (TME),

PL : Oh Tuhan yang Maha Kuasa, mohon Engkau beri kami ilmu yang banyak agar pelaksanaan proyek/kegiatan lembaga bisa berhasil.

TME : Setuju, ini sudah janji-Ku kepada hamba-hamba-Ku, kalau mereka memohon kepada-Ku, maka permohonan itu akan Kukabulkan. Tetapi sudahkah anda ambil langkahlangkah mengurangi berbagai resiko kegagalan? 
PL: Sudah, Oh Tuhan yang Maha Mengetahui. Kami sudah mempelajari berbagai resiko ini dan sudah mengadakan persiapan-persiapan dan mengambil langkah-langkah mengatasi resiko. Tetapi yang namanya resiko, menurut pemahaman kami manusia, memiliki ketidakpastian mengenai terjadinya. Ketidakpastian ini hanya Engkau yang sepenuhnya mengetahui dan menguasai. Selain itu, di balik resiko yang kami lihat, ada resikoresiko lain yang berlapis-lapis yang sulit kami jangkau walau dalam pemikiran sekalipun; apalagi menentukan langkah-langkah mengatasinya.

TME : Kalau sudah, baguslah. Yang penting bagimu adalah memanfaatkan seluruh kemampuan yang ada padamu. Memanfaatkan kemampuanmu secara maksimal adalah tanda engkau bersyukur atas segala pemberianKu kepadamu. Juga dalam proses pelaksanaan kau perlu menghormati manusia dengan melakukan tata pengelolaan yang baik. Ketahuilah bahwa manusia adalah wakilKu di bumi. Tetapi hati-hati jangan kau jadikan manusia apalagi materi sebagai gantiKu. Kau harus sadari betul Keesaan Dzat-Ku, Keesaan Sifat-Ku, dan Keesaan Karya-Ku. Kalau sudah kau lakukan semua ini, berdoalah dan nanti pada saatnya akan Ku kabulkan.

Kedua, penggunaan pertumbuhan ekonomi tinggi sebagai basis idiologi operasional tidak dikehendaki adalah bahwa dalam praktek dialog sebagaimana dicontohkan di atas sulit terjadi. Sebaliknya benar dan salah cenderung didominasi oleh pertimbangan materi semata. Sebagai contoh adalah posisi keuntungan dalam dunia bisnis. Keuntungan itu hanya diperuntukkan kepada pemilik saham. Tujuan manajemen perusahaan adalah memaksimalkan nilai saham atau "shareholder value". Alasan yang diberikan adalah bahwa pemegang saham telah menanam modal pada usaha tersebut dan oleh karena itu mereka adalah yang akan memperoleh keuntungan atau menderita kerugian. Tetapi kita mengetahui bahwa sesungguhnya yang menanggung resiko akan kegagalan suatu usaha jauh lebih luas dari pemegang saham. Kemudian yang membuat berhasil suatu usaha bukanlah hanya modal. Tetapi idiologi operasional materi merujuk hanya kepada pemegang saham.

Di bidang pembangunan ekonomi secara keseluruhan, menjadikan pertumbuhan ekonomi tinggi sebagai idiologi operasional, sebagai tujuan utama sekaligus cara utama, akan menjadikan pertumbuhan ekonomi tersebut sebagai hal yang berlawanan dengan pengakuan terhadap Keesaan Tuhan, baik dalam Dzat-Nya, dalam Karya-Nya maupun dalam Sifat-Nya. Jadi idiologi operasional materi mengingkari keimananan kepada Tuhan Yang Maha Esa. Yang berkembang adalah nilai-nilai moral subyektif berbasis materi.

Implikasi dari dua kelemahan dasar dari idiologi operasional pertumbuhan ekonomi tinggi. sebagaimana yang dikemukakan di atas ialah bahwa regime pembangunan yang terus menggunakan idiologi operasional ini akan terus mendapat tanggapan negatif dari umat beragama khususnya umat Islam. Memang tanggapan negatif ini mungkin bisa 
diatasi negara dengan cara turut serta mensponsori kegiatan-kegiatan keagamaan seperti membuat aturan libur pada hari-hari besar keagamaan, turut serta mensponsori langsung atau tidak langsung kegiatan tablig akbar dan "dzikir nasional", dan lain lain. Kegiatan kegiatan ini pada dirinya baik, tetapi kalau kegiatan-kegiatan ini dimaksudkan untuk menutupi hal sesungguhnya bahwa idiologi operasional pembangunan masih tetap berbasis materi dalam bentuk pertumbuhan ekonomi tinggi, maka kedok ini akan terbuka cepat atau lambat. Di alam kebebasan informasi, terbukanya kedok ini akan lebih banyak 'cepatnya' daripada 'lambatnya'. Semakin kedok ini terbuka semakin regime pembangunan tidak mendapat dukungan umat beragama.

Ketiga, manfaat jangka pendek dari penggunaan pertumbuhan ekonomi tinggi akan cenderung mendukung penggunaan idiologi ini selanjutnya. Buktinya adalah bahwa pada saat ini walaupun telah begitu banyak bukti akan kegagalan idiologi operasional pertumbuhan ekonomi, namun pemerintah Indonesia masih menggunakan idiologi ini sebagaimana terlihat dalam Rencana Pembangunan Jangka Menengah Nasional 2004-2009 yang sudah dibahas sebelumnya.

Dapatlah disimpulkan, semakin pertumbuhan ekonomi tinggi dicapai, semakin banyak permasalahan yang diakibatkanya kalau tetap tidak ada perubahan paradigma dan kebijakan. Pengangguran bertambah terus dan dengan pertambahan pengangguran ini meningkat pula berbagai ragam permasalahan dalam berbagai bidang kehidupan. Kerusakan lingkungan hidup akan bertambah berat. Keberlanjutan pembangunan bangsa tidak mungkin terwujud karena kurang didukung oleh pengembangan kelembagaan termasuk kepemimpinan yang konsisten dengan prinsip-prinsip pokok yang telah disepakati. Sebaliknya secara kelembagaan dan sistemik, terjadi pengingkaran terhadap keesaan Tuhan Yang Maha Esa dalam berbagai dimensi. Semakin pertumbuhan ekonomi tinggi dikejar, semakin nyata pengingkaran terhadap Ketuhanan yang Maha Esa dan Kemanusiaan yang Adil dan Beradab dan semakin dalam bangsa Indonesia terjerumus kedalam lembah dan lilitan permasalahan yang semakin sulit diatasi dan dukungan rakyat terhadap regime pembangunan akan semakin hilang. Hal ini tentu amat merugikan bagi terus tegaknya NKRI.

\section{Kemampuan Manusia Sebagai Idiologi Operasional}

Jelaslah bahwa idiologi pertumbuhan ekonomi perlu digantikan dengan idiologi operasional yang lebih sesuai. Tetapi apa gantinya? Gantinya adalah idiologi operasional berbasis manusia dan nilai nilai moral obyektif. Nilai nilai moral obyektif adalah nilai nilai moral yang digali dari prinsip Ketuhanan Yang Maha Esa. Jadi nilai operasional pengganti itu bertujuan mewujudkan kemampuan manusia yang tinggi berbasis nilai-nilai moral obyektif dalam mengupayakan cita-cita yang diemban. Ini artinya tujuan operasional utama suatu lembaga manusia adalah meningkatkan kemampuan para manusia yang terlibat dalam mengupayakan cita-cita. Ini juga berarti meningkatkan kemampuan manusia mengatasi unsur unsur negatif yang muncul atau berkaitan dengan pencapaian cita cita. Tetapi apa cita-cita yang perlu 
diupayakan sejalan dengan pesan dalam Pembukaan Undang Undang Dasar 1945? Jelas ia bukan hanya kekayaan materi walaupun kekayaan materi perlu merupakan komponen dari cita-cita tersebut.

Tetapi bagaimana rumusan operasional cita-cita yang terkandung di dalam UUD 1945. Di masa silam di era idiologi operasional, materi ini dikemukakan dengan rumus menciptakan masyarakat "adil makmur". Dalam kenyataannya, adil makmur utamanya diartikan sebagai keadilan di bidang ekonomi. Agaknya inilah yang telah mendukung begitu berperannya pemikiranpermikiran ekonomi/materialistis dalam pembangunan bangsa. Untuk masa sekarang dan masa depan ide masyarakat adil-makmur perlu termuat dalam ide operasional yang lebih mencakup sehingga prinsip Ketuhanan Yang Maha Esa dan Kemanusiaan yang Adil dan Beradab (termasuk ide adil makmur) termasuk secara operasional di dalamnya. Ide operasional yang lebih mencakup itu ialah terwujudnya masyarakat moral. Masyarakat moral ialah sebuah masyarakat yang dibangun di atas nilai-nilai moral berbasis Ketuhanan yang Maha Esa dan Kemanusiaan yang Adil dan Beradab. Kemudian, oleh karena dunia ke depan adalah dunia penuh persaingan, maka masyarakat moral itu perlulah memiliki daya saing tinggi. Dengan daya saing tinggi dimaksudkan daya saing yang dilandasi dengan nilai-nilai moral; berlomba-lomba berbuat kebaikan bagi kesejahteraan manusia dan keterpeliharaan alam. Dengan demikian ide operasional untuk mengejawantahkan UUD 1945 adalah terwujudnya masyarakat madani yang bermoral dan berdaya saing tinggi. Jadi kemampuan manusia yang perlu diciptakan itu adalah kemampuan untuk mewujudkan masyarakat madani yang bermoral dan berdaya saing tinggi.

Tetapi apa secara lebih konkrit isi dari masyarakat madani yang bermoral dan berdaya saing tinggi itu? Kita dapat mencacu kepada "maqasid syariah", sebagaimana yang dirumuskan sarjana muslim Imam Gazali (1998) dan meliputi ketaqwaan dan keimanan, kecerdasan, mutu keturunan, mutu kehidupan dan kemampuan meningkatkan kekayaan materi. Unsur unsur inilah yang perlu dikemas secara operasional pada berbagai tingkatan pelaksanaan pembangunan, baik dalam tujuan utama maupun sebagai cara utama mengupayakan tujuan. Rumusan ini terasa dan terlihat cukup komprehensif mencakup maksud utama diturunkannya kitab kitab suci melalui para rasul termasuk kitab suci Al-Qur'an melalui Muhammad SAW. Walaupun dalam kemasan ini Tuhan Yang Maha Esa dan manusia menjadi komponen-komponen utama namun sumber daya alam dan lingkungan hidup sebagai amanah dariNya, tidak boleh diperlakukan secara semenamena, umpamanya dieksploitir bagi kepentingan materi sekumpulan kecil manusia. Idiologi operasional yang dipancarkan dari rumusan yang demikian jauh lebih mencakup dari sekadar pertumbuhan ekonomi tinggi. Bilamana negara Republik Indonesia mengadopsi rumusan ini maka akan nyatalah kemampuannya merumuskan niat dasar secara operasional untuk apa NKRI diproklamirkan pada tahun 1945.

\section{MAKSIMISASI KEMAMPUAN MANUSIA DAN KEBEBASAN}

Kebebasan manusia sejalan dengan kemampuan manusia tetapi tidak bisa 
digunakan dalam perencanaan strategis pembangunan.

Kekurangpuasan dengan pertumbuhan ekonomi sebagai sasaran utama dalam pembangunan, khususnya bagai dunia ketiga sudah banyak dikemukakan oleh para sarjana pembangunan termasuk dari kalangan ekonom. Salah seorang sarjana tersebut adalah Amartya Sen, seorang pemenang hadiah nobel ekonomi. Ia mengemukakan pemikiran bahwa yang dituju dalam pembangunan adalah kebebasan manusia (Amartya Sen, 2000). Ide kebebasan manusia sebagai sasaran utama amatlah menarik.

Dalam kaitan ini, apakah kemampuan manusia sebagaimana yang dianjurkan di sini sejalan atau searah dengan kebebasan sebagaimana yang dianjurkan oleh Sen? Jawabnya adalah memang searah. Kesearahan kedua konsep ini, kemampuan manusia dan kebebasan, terlihat jelas dalam arti yang diberikan Sen kepada kemiskinan sebagai situasi hilangnya kemampuan untuk menjalani kehidupan sesuai nilai-nilai yang dianut (Amartya Sen, 2000:87-111).

Sudah barang tentu, melihat pembangunan suatu bangsa sebagai maksimisasi kebebasan manusia adalah hal yang sah-sah saja. Tetapi konsep kebebasan begitu luas, yang mencakup proses-proses dan sekaligus juga komitmen dan keadaan-keadaan manusia pada saat tertentu di tempat tertentu, sehingga sulit untuk dijadikan sebagai pegangan operasional. Sulit untuk menjawab pertanyaan bilamana kebebasan manusia sudah maksimal atau belum, sebab tidak adanya ukuran objektif yang dapat digunakan sebagai acuan sebagaimana tersedianya ukuran-ukuran objektif yang menyangkut kemampuan manusia. Dan ini diakui sendiri oleh Sen. Keragaman yang tercakup dalam konsep kebebasan atau "freedom" tidak memungkinkan ditetapkannya suatu ukuran umum yang mencakup berbagai situasi kemanusiaan dalam berbagai ragam kelembagaan, tempat dan waktu. Oleh karena itu dari segi manajemen strategis pembangunan suatu bangsa, yang menjadi perhatian utama dalam tulisan ini, maka kebebasan ini sulit digunakan sebagai pegangan operasional. Masalah pembangunan di dunia ketiga termasuk Indonesia adalah masalah pelaksanaan dan bukan masalah kurangnya ide-ide besar seperti kebebasan atau "freedom".

\section{KESIMPULAN}

Apakah yang dapat disimpulkan mengenai kemungkinan keberhasilan pelaksanaan RPJMN 2004-2009? Berdasarkan pengalaman-pengalaman yang ada, masa lalu maupun masa kini, dan ide-ide paradigmatis yang terkandung di dalam RPJMN 20042009 maka dapat disimpulkan bahwa kemungkinan berhasilnya dilaksanakan rencana pembangunan tersebut adalah kecil sekali. RPJMN 2004-2009 ini mengandalkan pertumbuhan ekonomi tinggi untuk meningkatkan kesejahteraan rakyat utamanya melalui penurunan tingkat pengangguran. Berdasarkan pengalaman sebelum krisis, pengangguran terbuka terus meningkat walaupun pertumbuhan ekonomi cukup tinggi yang didukung investasi dan ekspor yang memadai serta stabilitas yang terpelihara. Untuk masa depan, walaupun pertumbuhan ekonomi yang diproyeksikan dalam RPJMN 2004-2009 dapat diwujudkan yaitu sebesar rata rata $6,6 \%$ per tahun, diperkirakan pengangguran terbuka tidak akan turun. Hal ini dikarenakan tingkat pertumbuhan sebesar $6,6 \%$ masih lebih 
rendah dari tingkat pertumbuhan sebelum krisis yang $6,8 \%$ per tahun. Idiologi operasional berbasis materi dalam bentuk pertumbuhan ekonomi tinggi serta prinsipprinsip pelaksanaan yang terkait dengan paradigma individualisme, yaitu komando, kontrol dan kompartementalisasi, yang dipergunakan di masa lalu, masih tetap dimanfaatkan dalam RPJMN 2004-2009. Apalagi bila diingat bahwa dengan adanya perkembangan teknologi yang terus menerus yang umumnya padat modal, maka setiap 1\% pertumbuhan ekonomi saat ini menghasilkan lapangan kerja yang lebih sedikit dibanding pada masa sebelum krisis. Jadi dapatlah diyakini bahwa pengangguran kecil kemungkinan akan turun dari tingkatan saat ini yang lebih dari $10 \%$ dari angkatan kerja. Namun demikian, dibandingkan dengan Repelita-Repelita yang lalu, RPJMN 20042009 ini lebih eksplisit mendukung pengembangan SDM melalui perluasan lapangan kerja sebagaimana yang tercermin dalam bab-bab pertanian, industri dan pengembangan usaha kecil. Juga RPJMN ini lebih mementingkan bidang kesehatan dan pendidikan. Maksud baik ini tentu perlu disambut baik.

Yang selalu menjadi masalah adalah bukan kekurangan kemauan baik tetapi kekurangmampuan dalam pelaksanaan. Kekurangmampuan ini diperkirakan akan terus mendera di masa datang (kecuali ada perubahan yang signifikan), sebab secara paradigmatis RPJMN ini tidak berbeda dari Repelita yang lalu-lalu. Pertama, adalah paradigma pengorganisasian yang masih menggunakan faham individualisme yang dalam praktek ditandai oleh keterpisahan satu agenda kegiatan dengan yang lain dan yang tidak memiliki fokus bersama atau kebersamaan. Masing-masing agenda kegiatan berjalan sendiri-sendiri baik antaragenda maupun dalam masing-masing agenda. Paradoks sebagaimana yang diisyaratkan oleh teorema ketidakmungkinan dibiarkan gentayangan menggerogoti efisiensi dan efektifitas pemanfaatan sumbersumber ekonomi. Kedua, terkait dengan faham individualisme adalah prinsip-prinsip pelaksanaan yang dipergunakan yaitu prinsip 3K; komando, kontrol, kompartementalisasi yang sudah tidak cocok di alam informasi, ilmu pengetahuan, globalisasi dan demokrasi yang membutuhkan prinsip prinsip yang lain dan berbeda. Ketiga, konsep manusia yang tercermin dalam RPJMN 2004-2009 adalah manusia pasif, yang kalau menduduki posisi kepemimpinan selalu berlindung pada atasan dan kurang berani mengambil resiko pasang badan untuk inovasi dan tanggung jawab. Jadi terdapat kelemahan-kelemahan paradigmatis dari segi keberhasilan pelaksanaan RPMJN ini.

Namun anggaplah kelemahan-kelemahan di atas dapat ditanggulangi dan RPJMN berhasil dilaksanakan sebagaimana adanya. Dapatkah keberhasilan demikian juga dianggap berhasil dari segi penerjemahan tujuan-tujuan pokok berbangsa dan bernegara sebagaimana tersimpul dalam Pembukaan Undang Undang Dasar 1945. Jawabannya tidak; sebab idiologi operasional yang dipergunakan menerjemahkan tujuan-tujuan yang ada pada Pembukaan Undang Undang Dasar 1945 adalah idiologi operasional materi. Kalaupun RPJMN berhasil dilaksanakan, maka masyarakat yang dihasilkan adalah masyarakat yang semakin materialistis dan individualistis dengan konsekwensi-konsekwensi negatif dalam berbagai bidang kehidupan yang segala 
sesuatunya akan membawa Indonesia semakin menjauh dari masyarakat yang diidam-idamkan. Segala sesuatu ini mengisyaratkan perubahan paradigma operasional dalam pembangunan bangsa.

Jadi ada dua masalah pokok yang dihadapi negara dan bangsa Indonesia saat ini. Yaitu, pertama, merumuskan kembali secara operasional niat dasar yang terkandung di dalam Pembukaan Undang Undang Dasar 1945. Atas dasar niat dasar operasional ini disusun program-program pembangunan bagi penyelesaian permasalahan-permasalahan pokok yang dihadapi bangsa. Perumusan kembali niat dasar operasional ini amatlah penting sebab dengan idiologi operasional materi dalam bentuk pertumbuhan ekonomi tinggi yang sekarang dianut, seolah-olah dikatakan bahwa perubahan dalam masyarakat Indonesia bisa diwujudkan dari luar diri manusia; padahal Al-Qur'an memberi petunjuk yang sudah umum diketahui di kalangan umat Islam bahwa perbaikan suatu kaum hanya bisa terwujud kalau ada perubahan dalam diri manusia-manusia yang terlibat. Dalam kaitan inilah diusulkan perlunya bangsa Indonesia mengadopsi niat dasar operasional Pembukaan Undang Undang Dasar 1945 dalam bentuk "Terwujudnya masyarakat madani bermoral dan berdaya saing tinggi". Inilah yang menjadi fokus operasional pembangunan bangsa pada berbagai tingkatan. Program-program pembangunan yang disusun mengacu kepada fokus ini.

Permasalahan pokok kedua adalah meningkatkan kemampuan negara dan bangsa untuk melaksanakan programprogram pembangunan. Dalam kaitan ini perlu ada perubahan paradigma pengorganisasian dari yang berbasis individualisme ke yang berbasis kebersamaan. Prinsip-prinsip manajemen yang dianut perlu diubah dari komando, kontrol dan kompartementalisasi menjadi kepemimpinan, inovasi dan jaringan berbasis musyawarah untuk mufakat. Perencanaan dan pelaksanaan perlu menyatu dan tidak terpisah; penyatuan ini perlu terlaksana dari lembaga pelaksanaan tertinggi yaitu Presiden dengan kabinetnya, sampai ke departemen-departemen dan daerah serta lembaga-lembaga swasta.

\section{DAFTAR PUSTAKA}

Amartya Sen, 2000, Development as Freedom, New York: First Ducher Books Edition, hlm. 87-111 dan 297.

Arrow's Impossibility Theorem, from Wikipedia, the free encyclopedia, website

Harian Kompas, 2006, 28 Februari, Jakarta, hal. 1

Harian Kompas, 2006, 4 Maret, Pengusaha Pesimistis, Jakarta, hal. 1.

Imam Gazali, 1998, The objective of the Shari'ah is to promote the welfare of human beings, which lies in safeguarding their faith, their life, their intellect, their posterity, and their wealth. Diterjemahkan oleh Muhammad Umar Chapra, dalam IRTI: Lessons In Islamic Economics, Jeddah, hal. 105.

John Geanakoplos, 2001, Three Brief Proofs of Arrow's Impossibility Theorem, Cowles Foundation For Research in Economics, Yale University, New Haven, Connecticut 06520-8281, June; http://cowles.econ.yale.edu/.

Majalah Tempo, 2005, Edisi 31 Januari-6 Februari, Jakarta, hal. 9. 
Republik Indonesia, 1994, Rencana Pembangunan Lima Tahun Keenam, 1994/951998/99, Buku I, Jakarta, hal. 83.

Republik Indonesia, 1994, Rencana Pembangunan Lima Tahun Keenam, 1994/951998/99, Buku I, Jakarta, hal. 86-87.

Republik Indonesia, 1994, Rencana Pembangunan Lima Tahun Keenam, 1994/951998/99, Buku I, Jakarta, hal. 87

Republik Indonesia, 2004, Agenda 100 Hari Pertama Kabinet Indonesia Bersatu, Jakarta: Bappenas. hal. 1-2.

Republik Indonesia, 2004, Rencana Pembangunan Jangka Menengah Nasional 2004-2009 (RPJMN), Jakarta, hal. Bagian V.34-6.
Republik Indonesia, 2005, Rencana Pembangunan Jangka Menengah Nasional Tahun 2004-2009, Daftar Isi

Republik Indonesia, 2005, Rencana Pembangunan Jangka Menengah Nasional, hal. Bagian V.34-1

Republik Indonesia, 2005, Rencana Pembangunan Jangka Menengah Nasional, hal. Bagian V.34-5

Republik Indonesia, 2005, Rencana Pembangunan Jangka Menengah Nasional, hal. Bagian VI.35-1

Republik Indonesia, 2005, Rencana Pembangunan Jangka Menengah Nasional Tahun 2004-2009, Jakarta, hal. Bag.I.18, 1-9, 1-10, 1-11 